J. of Modern African Studies, 59, 4 (2021), pp. 439-462 $\quad$ (c) The Author(s), 2021 . Published by Cambridge University Press. This is an Open Access article, distributed under the terms of the Creative Commons Attribution licence (http://creativecommons.org/licenses/by/4.o/), which permits unrestricted re-use, distribution, and reproduction in any medium, provided the original work is properly cited.

doi: $10.1017 /$ SoO22278X21000252

\title{
Commissions of inquiry and pathways to accountability in Plateau State, Nigeria*
}

\author{
Marjoke OOSTERom \\ Institute of Development Studies, University of Sussex, UK \\ Email: M.Oosterom@ids.ac.uk \\ Dung Pam SHa \\ University of Jos, Nigeria
}

Email: dungpamsha@gmail.com

and

Caitriona Dowd

Dublin City University, Ireland

Email: Caitriona.Dowd@dcu.ie

A B S T R A C T

For decades, Plateau State in Nigeria's Middle Belt has witnessed repeated ethnoreligious violence. Over this period, both state and federal governments have established formal Commissions of Inquiry (COIs) in response to unrest, tasked with investigating violence, identifying perpetrators, and-ultimately-strengthening accountability. While commissions' mandates and specific outcomes varied, there

\footnotetext{
*Research for this article was undertaken as part of the Action for Empowerment and Accountability research consortium convened by the Institute of Development Studies (grant number PO 7239), which is funded by the UK Foreign, Commonwealth \& Development Office (FCDO); however, the views here expressed do not necessarily reflect the UK government's official policies. We wish to thank Dr Adakai F. Amayah and Dr Plangsat Dayil of the Department of Political Science, University of Jos, Nigeria, for their time and dedication to the project, and the interviews they have conducted. We also thank all research participants for the generous time offered to researchers.
} 
is general consensus that inquiries have been largely ineffective at securing justice or establishing accountability for violence. This study seeks to understand the expectations placed on, and role of, COIs in Plateau State as pathways to formal accountability in a context of recurring violence. We argue that COIs are embedded in the complex, multilevel networks and politics of state and non-state institutions. Civil society, in turn, has diverse expectations and demands, and articulates these in fragmented ways. As a result, COIs served primarily as another avenue for interest-based negotiations.

Keywords: Civil society; accountability; violence; Commissions of Inquiry; Nigeria

I N T R O D U C T I O N

Plateau State in Nigeria's Middle Belt has witnessed decades of repeated ethnoreligious violence. In response to waves of unrest, between 1994 and 2008, successive state and federal governments established Commissions of Inquiry (COIs) to investigate immediate triggers and structural causes, document violence, hear testimony, and make recommendations for government action. However, multiple COIs have had only limited success in delivering accountability and preventing further violence (Gofwen 2011; Sayne 2012; Oyieke 2020). While efficacy and impact could be measured in several ways, if we accept the extent to which recommendations of a commission have been implemented by government as a key metric of impact (see Oyieke 2020), it is notable that no COI resulted in legal convictions for named perpetrators; nor is there evidence of appointments or removal from public office attributable to the work of COIs.

This study seeks to understand why formal accountability mechanisms have failed in this context. While conflict in Plateau State has been well-documented (HRW 2009, 2013; Higazi 2011; Sayne 2012) and COIs in Nigeria more widely have received some scholarly attention (Yusuf 2018; Oyieke 2020), research on COIs in Plateau State is very limited, and the role of civil society action in relation to COIs in this context has hardly been addressed at all. Existing literature on COIs largely emphasises one of two explanations for limited effectiveness. First, that the formal, institutional structure and position of COIs within the state architecture is a determining factor. Where commissions have weak mandates, limited independence, and restricted powers of enforcement, it is argued that they will be less effective (Hayner 2006). A second explanation emphasises the role of wider social relations in the work of commissions. Where COIs, as formal state-initiated institutions, are not under sustained pressure from civil society to deliver on mandates, this will limit their impact (Maclean 2001). This study advances our understanding of formal accountability processes in fragile and conflict-affected settings by drawing together research on formal accountability institutions, the role of civil society, and conflict itself.

Drawing on a series of qualitative key informant interviews in Jos, Plateau State, we explore why recent COIs, as formal accountability mechanisms, have 
not produced accountability. The study conceptualises accountability as the interaction between formal institutions and civil society actors in order to attain enforcement of, for instance, legal sanctions (Fox 2007a, 2007b, 2016; Goetz \& Jenkins 2001; Peruzzotti 2012). It draws on literature on fragility and conflict that has demonstrated how networked governance and fragmented authority, alongside a divided civil society, shape the functioning of formal accountability institutions (Orjuela 2005; Hagmann \& Péclard 2010; Leonard 2013).

Through this, we demonstrate how COIs are embedded in, and interact with, other political institutions and civil society. This strongly influences processes and outcomes. While various COIs recommended the prosecution of senior figures, 'hard' accountability through legal justice or removal of officials from office, was not enforced. This resulted from both the networked and fractured nature of multilevel governance, coupled with divided civil society unable to exert sufficient pressure. The politically embedded nature of institutions and parallel divisions in civil society are both features of the wider political and conflict context, and have in turn compounded a lack of trust in COI processes and the state.

This has implications for the potential of COIs to deliver 'hard' accountability in particular. In contexts with a long legacy of inter-group violence, divided civil society and contested and fragmented authority, institutional mechanisms for accountability such as commissions may not be effective. Where civil society has disengaged from formal accountability processes, interventions seeking to prevent violence may be more effective if they, instead, support locally led initiatives for peacebuilding and reconciliation.

The article is structured as follows. The first section reviews existing literature on COIs and factors influencing their functioning in fragile settings. The following section presents an overview of conflict and COIs in Plateau State. We then outline the research design, before the first empirical section analyses the politics and networks that have affected COIs. The next empirical section discusses how civil society has engaged with, and contested, COIs in various ways. We conclude by discussing how this has undermined the potential of COIs to deliver accountability.

\section{COMMISSIONS OF INQUIRY AND ACCOUNTABILITY}

COIs are official, normally independent, temporary bodies established to investigate and document episodes of violence and abuse and make recommendations for action (Hayner 2006; Probert 2017; Probert \& Heyns 2020). COIs have a long history in Africa (Jain 2020), where approximately 70 national commissions were established between 1990-2016, with 12 in Nigeria alone, representing the largest number on the continent (Jain 2020; Probert \& Heyns 2020). This demonstrates COIs' relevance not only in Nigeria, but in wider regional and global processes of formal accountability.

COIs are premised on the understanding that, inter alia, 'a legacy of grave and systematic [human rights] violations generates obligations that the state 
owes to the victims and to society' (Méndez 1997: 255). Commissions vary in their legal underpinnings: some can compel witnesses to appear, while others rely on voluntary cooperation. Some hold public hearings, while others are closed and their findings presented (if at all) only on publication of a report (Hayner 2006). COIs usually do not have legal powers to prosecute, and their relationship with prosecutorial and judicial bodies can be complex (Kim \& Sikkink 2010; Bakiner 2014). They also, typically, have a narrower remit to investigate specific episodes of violence, rather than long-running abuse or regimes (Hayner 2011: 11-13).

How does the work of COIs link to conceptualisations of transparency and accountability? Within commissions, transparency revolves around the notion of 'truth': testimonies from survivors, witnesses and perpetrators about what happened, to inform victims, family and society at large. Commissions can therefore potentially serve important functions acknowledging and addressing historical injustice and violence (Balint et al. 2016). Their mandates can include proposing prosecution or other punishment for perpetrators, and/or proposing reparations or other measures for victims (Méndez 1997: 261). In this way, proponents contend that COIs are a more 'flexible, participatory and open mechanism' than 'criminal investigation' alone (Probert 201 7: 1).

\section{Institutional dilemmas of commissions}

COIs are 'transversal accountability' institutions: formal, state-initiated institutions that bring together state and societal actors (Fox 2007a: 31). This builds on O'Donnell (1999, 2003), who refers to institutional oversight and checks and balances within the state as 'horizontal accountability' (see also Peruzzotti \& Smulovitz 2000, 2006; Ackerman 2004). However, the extent to which commissions deliver on this varies.

Through their emphasis on finding out what happened, the work of commissions can contribute 'answerability': the justification or explanation for actions by those involved (Fox 2007b: 667). Given their investigative powers, commissions can be expected to produce 'meaningful' answerability (Fox 2007a, 2007b: 667) by compiling information on violent events, perpetrators and impacts. Answerability is considered the 'soft' dimension of accountability. Many feel, however, that answerability falls short of real accountability if it remains without consequences (Fox 2007b: 668). By contrast, 'enforcement' is the 'hard' dimension: it leads to sanctions such as court convictions and removal from office, and/or compensation and remediation (Fox 2007b: 668). While some commissions are prohibited from naming perpetrators, those in Plateau State have recommended named perpetrators for prosecution. The 'naming of names', according to Greenawalt (2000: 190), is a form of 'minimal accountability' as it creates a public record of suspects and leads to informal social sanction, even without formal penalties by the state. However, it remains a contested issue in many contexts and civic groups have argued that it risks a 'blanket amnesty' in some cases (Greenawalt 2000: 190). 
Given their institutional and legal limitations, COIs need the buy-in of other actors in the political system to implement recommendations, in particular for 'hard' accountability measures that require cooperation of public prosecutors and courts, and a range of actors to remove power holders responsible from office. Thus, COIs are part of a dynamic involving multiple political actors. Some therefore caution against concluding that particular commissions have been 'successes' or 'failures', given their embedded nature. As Probert (2017: 9) notes:

It is very important to distinguish between commissions of inquiry as a potential tool (or mechanism) of accountability from the entity which ultimately has the responsibility to drive a process of accountability, namely the state ... Commissions can be part of successful or unsuccessful processes of accountability ... but often the implementation of their recommendations lies outside their own powers.

These institutional explanations, however, have developed largely separate from the literature on governance in fragile contexts. This is notable, insofar as COIs are often established in such contexts, and so the dynamics of fragility should be of central concern. These contexts are often characterised by a 'legal accountability deficit' (Peruzzotti \& Smulovitz 2006): an absence of strong, neutral political institutions that can take measures to deliver 'hard' accountability. Informal behaviours and misuse of office by state actors can also interfere with accountability processes (Ackerman 2004; Peruzzotti 2014; Fox 2016).

Whereas research on the institutional dimensions of COIs in a wide range of settings has been concerned with 'the asymmetric power of the state' affecting commissions' independence (Probert \& Heyns 2020: 11 ), literature on fragile and conflict-affected contexts suggests that institutions in these settings are not only 'embedded', but operate within a system of authority so fragmented, that governance is truly 'hybrid'. In these contexts, power is less asymmetric, than it is negotiated and produced through multiple state and non-state forms of authority (Menkhaus 2008; Hagmann \& Péclard 2010; Titeca \& De Herdt 2011 ; Bagayoko et al. 2016). Leonard (2013) argues that all governance is multilevel and networked, including to communities and external actors. Competing forms of authority are likely to undermine formal justice institutions. Therefore, the networked nature of institutions, and their vulnerability to interference, may be factors shaping COIs' performance specifically in more fragile settings, of which Plateau State is an example.

Fragile contexts may also undermine the work of COIs through the threat of violence itself. A vast literature, developed particularly around truth commissions, discusses the trade-off between justice and accountability on the one hand, and peace and reconciliation on the other (Greenawalt 2000; Rotberg 2000; Rotberg \& Thompson 2000). Stakeholders may need to accept that (a degree of) amnesty is granted to perpetrators in exchange for obtaining information about past events; the prevention of future injustice; and/or peace. If a COI faces a similar trade-off, then answerability obtained through their work may not lead to 'hard accountability'. 
These studies emphasise COIs' variable performance through their official mandate and relationship to other political institutions. However, while these explanations highlight the complexity of governance, they tend to minimise the role of civil society and the wider public in shaping how institutions function. The next section elaborates on this.

\section{Civil society and Commissions of Inquiry}

The debate on accountability politics has emphasised the role of civil society actors in producing 'vertical' accountability (whereby citizens and civil society have control over the state, such as through elections), but also in exercising pressure to bolster horizontal accountability. They can do this by empowering, or demanding the creation of, accountability agents within the state (Fox 2007a, $2007 b)$, such as demanding that a COI is established, lending it legitimacy and influencing its process.

External pressure by societal actors is often required to 'trigger' official checks and balances (Fox 2007a: 32), and strategic, cross-actor collective action is associated with pushing for accountability (Fox 2015, 2016). Indeed, several studies suggest COIs are most effective when they result in civil society mobilisation around implementation of policy recommendations or pressure to reform political processes (Crocker 2000; Bakiner 2014; Probert 2020). In the context of truth commissions, for example, Zvobgo (2020) demonstrates that the strength of domestic civil society, combined with the actions of international human rights groups, influences the adoption of truth commissions. The length of time commissions often require to investigate and publish their report, however, can mean that by the time they have developed recommendations, civil society interest has waned (Probert 2017). This suggests that where civil society action is limited or delayed, the impact of commissions may also be.

However, there is still limited understanding of how dynamics of fragility influence the interaction between societal actors and COIs. In many fragile settings, civil society itself may be weak, lacking coordination (Crocker 2000: 113), or focused on localised self-help activities, rather than on exerting direct policy influence. Conflict research has clearly demonstrated how civil society may be highly diverse and fragmented along identity lines (Crocker 2000; Orjuela 2005; Belloni 2008). If civil society is indeed fragmented or networked to different parts of the state that are in competition, then different sections within civil society may work in favour of and against impunity (Fox 2007 $a$ : 34). It is increasingly recognised that accountability is attained through a combination of strategies, including the collaboration between civil society and pro-accountability actors at different state levels (Fox 2015, 2016; Joshi 2017). While alliances with pro-accountability agents within the state can be helpful, these actors may be too weak to pro-actively counter those who undermine accountability processes (Fox 2020: 13). Alliances are unlikely to be straightforward in contexts where political institutions are weak and where both state authority and civil society are fragmented. 
Finally, the dynamics of violence itself, and its often discriminatory and targeted nature - for example, in targeting particular groups - means that experiences of violence vary. This renders the establishment of a singular, factual and undisputed narrative of events extremely challenging (Ross 2010; Kent 2016). It is also possible that some constituencies within civil society see ensuring future security and enhancing accountability for past violence as mutually incompatible, and either accept or reject trade-offs towards this end (Méndez 1997).

This highlights a number of dilemmas facing COIs, and potential explanations for their performance, that are relatively neglected to date in the literature on formal accountability pathways. The next section explores these in the context of Plateau State, Nigeria.

\section{PLATEAU STATE: VIOLENCE AND ACCOUNTABILITY}

Nigeria's Middle Belt has witnessed recurring unrest over several decades, often at critical junctures, such as elections (Ostien 2009; Krause 201 1; Angerbrandt 2018; Madueke 2018a). According to records of violence between 2000 and 2018, Plateau State witnessed the second-highest levels of political violence and conflict-related fatalities in Nigeria (see Figure 1; Raleigh et al. 2010). Jos, the capital of Plateau State, is one of the worst-affected locations, where more than 4000 people were killed in cycles of violence between 2001 and 2010 (HRW 2013).

The conflicts involve a number of predominantly Christian communities on the one hand, and predominantly Muslim Hausa-Fulani on the other. ${ }^{1}$ The former are considered by some to be 'indigenous'; while the latter are categorised by some as 'settler' groups, who migrated to the region more recently.

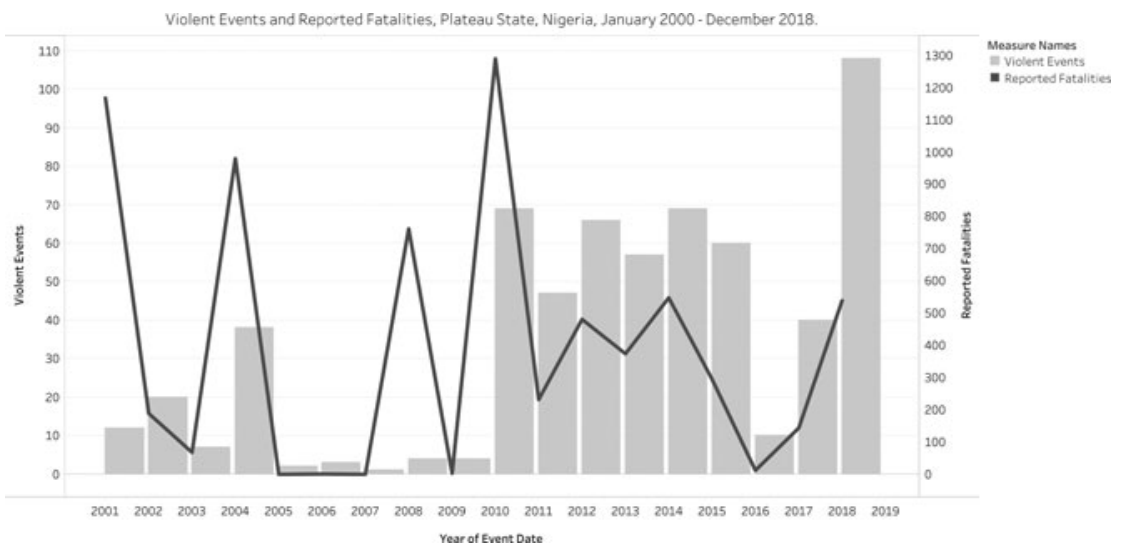

Figure 1.

Violent events and reported fatalities, Plateau State, Nigeria, January 2000December 2018. Data source: Armed Conflict Location \& Event Dataset (ACLED). 
The Constitution of Nigeria grants relatively more rights to those who belong to 'indigene' groups, contributing to deep divisions (Ostien 2009; Krause 2011; Sayne 2012). While referred to as 'settlers', many have lived in Plateau State for many generations and in Jos, many have repeatedly claimed to be among the original inhabitants (Krause 2011: 24). In response, Plateau State has, over time, created new boundaries and smaller subnational units in an attempt to diffuse conflict, with limited success (Angerbrandt 2015).

Alongside structural drivers, violence can also be attributed to more proximate factors. Police and security forces have often failed to adequately protect civilians and, in some cases, have targeted civilians during their operations, leading to deep distrust and perceptions of partisanship (Higazi 2011: 20; Sayne 201 2; Madueke 2018b). Politicians and religious elites have also been accused of complicity in violence, by politicising identity, interfering in elections and commercial land deals, and some directly mobilising attacks (Sayne 2012:8).

\section{Commissions of Inquiry as an accountability mechanism in Plateau State}

Among other measures, multiple COIs have been established and tasked with delivering accountability in response to recurring violence in Plateau State (Krause 2017; Oyieke 2020). Table I presents an overview of COIs established there since 1994 by either state or federal government.

The last COI was operational in 2009 (although COIs have continued to be established elsewhere in Nigeria, see Oyieke 2020). After this date, the government resorted to the use of committees only in Plateau State, which differ from COIs in the process of investigation. Throughout this paper, different COIs will be distinguished by referring to their chairperson. Each COI was tasked with investigating a specific episode of violence, identifying and naming perpetrators, and issuing recommendations. The authority responsible for establishing COIs has varied: governments at both the federal and state level have argued that they have a statutory responsibility to investigate violence (discussed further below).

\section{RESEARCH DESI G N}

The study draws on 34 key informant interviews with civil society actors and government officials who directly engaged with COIs (see Appendix 1). Interviews were held between January 2018 and November 2019. Participants were identified using snowball sampling, drawing on the network of the University of Jos. The authors endeavoured to include a range of perspectives from all groups: 11 out of 34 respondents were Muslim; and five respondents represented youth organisations. All participants were directly involved in one or more COIs either as a member, government official, or civil society actor.

The study focuses on COIs rather than advisory panels and committees, although sometimes participants compared these. Since the Ajibola Commission was the most recent (operational in 2009, report released in 
TABLE I.

Commissions of Inquiry and committees investigating violence in Plateau State.

\begin{tabular}{|c|c|c|c|c|}
\hline Year & Commission & $\begin{array}{l}\text { Authority } \\
\text { responsible }\end{array}$ & $\begin{array}{l}\text { When/whether } \\
\text { report was released }\end{array}$ & $\begin{array}{l}\text { Report recommended } \\
\text { named individuals for } \\
\text { prosecution? }\end{array}$ \\
\hline 1994 & $\begin{array}{l}\text { Justice Aribiton Fiberisima } \\
\text { COI (1994) }\end{array}$ & State & $\begin{array}{l}\text { Report released - } \\
1994 \text {. White } \\
\text { paper released - } \\
2004\end{array}$ & Yes \\
\hline 2001 & Justice Nikki Tobi COI & State & $\begin{array}{l}\text { White paper } \\
\text { released-2010 }\end{array}$ & Yes \\
\hline 2001 & $\begin{array}{l}\text { Justice Jummai Sankey } \\
\text { Judicial COI }\end{array}$ & State & $\begin{array}{l}\text { Report submitted, } \\
\text { no white paper }\end{array}$ & Yes \\
\hline 2001 & $\begin{array}{l}\text { Justice Suleiman Galadima } \\
\text { Commission }\end{array}$ & Federal & $\begin{array}{l}\text { Report submitted, } \\
\text { no white paper }\end{array}$ & Yes \\
\hline 2002 & $\begin{array}{l}\text { Justice Felicia Dusu COI } \\
\text { Judicial COI }\end{array}$ & State & $\begin{array}{l}\text { Report submitted, } \\
\text { no white paper }\end{array}$ & Yes \\
\hline 2002 & Justice Okpene COI & Federal & $\begin{array}{l}\text { Report submitted } \\
\text { in } 2002, \text { not clear } \\
\text { if white paper } \\
\text { produced }\end{array}$ & Yes \\
\hline 2002 & $\begin{array}{l}\text { Rev. Dr Padang Yamsat } \\
\text { High Powered Committee } \\
\text { on Peace and Security in } \\
\text { Plateau State }(2002)\end{array}$ & State & $\begin{array}{l}\text { Report submitted } \\
\text { in } 2002\end{array}$ & Yes \\
\hline 2004 & $\begin{array}{l}\text { Presidential Peace Initiative } \\
\text { Committee }\end{array}$ & Federal & No information & No information \\
\hline 2005 & $\begin{array}{l}\text { Mr Musa Izam } \\
\text { Administrative Committee }\end{array}$ & State & $\begin{array}{l}\text { Report submitted } \\
\text { in } 2005\end{array}$ & Yes \\
\hline 2005 & $\begin{array}{l}\text { Justice Constance Momoh } \\
\text { Judicial Commission of } \\
\text { Inquiry to look into } \\
\text { conflicts in Quanpan LGA }\end{array}$ & State & $\begin{array}{l}\text { Report submitted - } \\
200_{5} \text {; not } \\
\text { released }\end{array}$ & Yes \\
\hline 2009 & $\begin{array}{l}\text { Major General Emmanuel } \\
\text { Abisoye Federal adminis- } \\
\text { trative panel }\end{array}$ & Federal & $\begin{array}{l}\text { The COI did not } \\
\text { carry out the } \\
\text { inquiry }\end{array}$ & Not applicable \\
\hline 2009 & Justice Bola Ajibola COI & State & $\begin{array}{l}\text { Report released- } \\
2009 . \text { White } \\
\text { paper }- \text { not } \\
\text { released }\end{array}$ & Yes \\
\hline 2010 & $\begin{array}{l}\text { Chief Solomon Lar and } \\
\text { Amb. Yahaya Kwande } \\
\text { Advisory Committee }\end{array}$ & Federal & $\begin{array}{l}\text { Report released- } \\
\text { May 2010. White } \\
\text { paper-not } \\
\text { released }\end{array}$ & $\begin{array}{l}\text { Affirms earlier reports } \\
\text { on the initiators and } \\
\text { perpetrators of } \\
\text { violence }\end{array}$ \\
\hline 2011 & $\begin{array}{l}\text { Shikh Ahmed Lemu } \\
\text { Committee }\end{array}$ & Federal & No information & No information \\
\hline
\end{tabular}

2014) many participants focused on this commission specifically in their responses as they recalled it most clearly. As such, the study is relatively more focused on this, but also considers participants' experiences with previous commissions. 
Nevertheless, in terms of limitations, it is important to note that respondents' accounts of historical COIs were susceptible to potential recall issues. To mitigate this, the authors conducted a review of media reports to verify details recounted in interviews. Moreover, while we do not suggest the sample of COIs discussed is either exhaustive, nor entirely representative, we suggest that through our analysis of these, we arrive at insights that can further understanding of the role of formal accountability institutions in Nigeria and beyond. Lastly, with regards to the scope of the study, while we include some limited discussion of the underlying conflict(s) that prompted the establishment of COIs in the first instance, a full discussion of these complex dynamics remains beyond the scope of this paper alone, where we focus instead on the COIs specifically.

THE EMBEDDEDNESS OF COIS IN THE POLITICS AND NETWORKS OF THE STA TE

The few existing studies on COIs in Plateau State emphasise that they are, in general, top-down instruments (Albert 1999) whose limited effectiveness can be explained by government's failure to follow up on recommendations (Gofwen 2011; Sayne 2012; Oyieke 2020). This section discusses the nature of networked governance in Plateau State, and how COIs are embedded in politics at federal and state government level and, by extension, in conflict dynamics themselves. This helps to explain why COIs have had limited success in producing 'soft' accountability, and have ultimately failed to produce 'hard' accountability. Consequently, we find that their lack of responsiveness has strengthened a sense of impunity and further deepened mistrust.

\section{Competing interests within the state}

Government inaction over implementing recommendations has been acknowledged by successive commissions. The Ajibola Commission report explicitly states that recommendations made by the Niki Tobi Commission and Fiberesima Commission were not implemented, and that this was 'one of the major remote causes' of the re-eruption of violence (Ajibola Commission of Inquiry 2009: 59-61). Both commissions recommended the prosecution of named individuals, and monitoring of certain organisations believed to have played a role in instigating violence (Ajibola Commission of Inquiry 2009: $5^{6-8)}$. Some respondents emphasised that the fact that COIs did not result in meaningful 'hard' accountability cannot be understood as a failure of the Commissions themselves, and instead highlighted wider government inaction. As one interviewee noted:

We cannot say outrightly that it is the fault of the commission itself, because they are the only ones, they are given assignment to do, but we expect that the government at the end of the day will implement the decisions of those commissions of inquiry. (Int. 1, 2018) 
In emphasising the role of government in the implementation of recommendations, respondents placed responsibility for accountability with wider institutions of public authority. While the state government did take some violence prevention measures in response to COI recommendations, nobody was prosecuted.

The question whether security concerns hampered the implementation of COI recommendations to prosecute provoked varied responses from civil society. Some respondents were critical about the government setting up COIs and identifying perpetrators if it was not prepared to prosecute. In interviews, all respondents noted that none of the named individuals were ever taken to court and convicted. As one interviewee exclaimed, 'They are today walking the streets of Jos as free men!' (Int. 25, 2018). A review of media articles confirmed that none of the individuals recommended for prosecution by the Ajibola Commission were indeed prosecuted. On the contrary, numerous figures who were accused of instigating violence continue to hold public office or prominent political roles (see Daushep 2018). Many respondents felt the risk of future violence by named perpetrators had been presented as an argument by successive governments, but one that primarily served to protect prominent figures from prosecution (Ints $7,14,16,17,2018$ ). Respondents highlighted what they felt was the effective impunity of government officials and politicians implicated in violence. This was considered a major reason for the delay in public release of reports, as well as lack of implementation.

By contrast, some respondents found the government's claim that it was better not to implement recommendations as it would provoke further violence, credible (Int. 8, 2018). Some named perpetrators were considered influential in their communities and, if arrested, they could instigate unrest. Other respondents pointed to specific recommendations that would have had security implications. The Ajibola Commission recommended redrawing territorial boundaries of Jos North LGA (Right to Know 2010: 8-9), which would likely provoke tensions and possibly new conflict, according to one respondent (Int. 22, 2018). Even those civil society representatives who were vocal about the lack of government responsiveness, acknowledged the risks of arresting highlevel officials. For example, one respondent stated that, if the recommendations for prosecution included in the Ajibola Report were implemented, this would very likely have triggered large-scale violence (Int. 6, 2018). One Muslim respondent remarked that prosecuting many of the high-profile Muslim leaders indicted in the report would not address 'any evil or vice, it will create more. It will make the state ungovernable' (Int. 31, 2019). When asked about the lack of prosecutions, a former Secretary to the State Government maintained that the challenges of compiling evidence had inhibited arrests of senior officials. He did not refer to public security as a reason and refuted the claim that the State Government was sustaining impunity (Int. 2, 2018).

Some respondents spoke of how such actors 'hold the state hostage' by threatening to trigger violence (Ints 14, 18, 2018). One highlighted that those in 
charge of handling reports are afraid of more senior officials: 'If they release the reports, it might hurt one or two persons and it will affect their [own] political career' (Int. 1, 2018). Another respondent stressed that recommendations to indict senior officials, party leaders and politicians can become 'political liabilities', and that pressing for those recommendations that are unpopular among a certain constituency is a risk as one might lose elections (Int. 6, 2018). The following respondent explained how impunity is the effect of informal, multilayered networks:

Every untouchable political actor is covered by a godfather. Secret cults in the polity ... and there are many of them, quite frankly. [They are] Well linked-up, well-connected nationally, internationally. Some of their names are there in the Commissions of Inquiry [reports]. I don't know how these people would be prosecuted. The moment you start, as a matter of fact you would ... you will hit the rocks. That is why the security agencies like the police would be reluctant to go arrest some of these characters. ... It means people are above the law. (Int. 8, 2018)

These accounts thus suggest that competing and networked interests within the state shaped the functioning and impact of COIs. The following section elaborates on how fragmentation and networks between the state and federal governments may further explain accountability outcomes.

\section{Multilevel networked governance and fragmented authority}

Across a range of stakeholders, consultations illustrate the dynamics of multilevel, networked governance and how the negotiation of justice by different actors sustains impunity. It is worth noting that the tensions surrounding levels of state and federal authority, detailed below, are not unique to the issue of COIs in Plateau State. They reflect broader issues related to federal governance and inter-group conflict in Nigeria (Suberu 1993, 2009; Angerbrandt 2015), and have affected the composition and establishment of COIs beyond Plateau State as well (Oyieke 2020).

One central theme among respondents was the role-and control-of security forces during and following crises. In one interview, a former State Governor of Plateau State reported he was convinced that the federal government was frustrating legal justice at state level. He argued that it was not the fear of renewed violence that stopped his government from implementing COI recommendations, but obstacles created by the federal government-controlled police force and army (Int. 29, 2018). By his account, security forces were instructed not to arrest any person indicted by COIs; and also not to implement more practical laws enacted to respond to COI recommendations, such as preventing the use of motorcycles in the city.

A respondent from a human rights organisation recalled that the federal government appointed former Commissioner of Police, Alhaji M.D. Abubakar, as the acting Inspector General of Police in 2012 (Obateru \& Binniyat 2012). Among other individuals, the Niki Tobi Commission had named Abubakar in its report as a perpetrator in the 2001 crisis. The government had named 
him in its White Paper and recommended his retirement (Obateru 2012). Two civil society actors interviewed stated they had alerted the state government to the appointment, who had publicly disapproved (Int. 23, 2018). Despite this, the appointment was not revoked: a failure for 'hard' accountability.

A second theme related to prosecution specifically, and judicial procedures more generally. With regards to lower-level perpetrators, one respondent observed that the state government did not follow due process and this hampered justice procedures (Int. 20, 2018). He recalled that during the 2008 crisis, many more suspects were arrested and imprisoned than ever before, but there was no capacity to properly investigate each case. Someone could be charged for the illegal possession of firearms if caught with one, but in most cases, there was insufficient evidence and investigative capacity to prosecute 'rank and file' suspects for more serious crimes, this respondent claimed. In his capacity as a lawyer, he had directly engaged with the Attorney General in 2008, requesting better documentation of evidence. In his view, the federal government intervened because the state government could not handle the cases properly. However, a lawyer and representative of Muslim communities argued the federal government intervened in 2008 because it had become aware of the many arbitrary arrests of Muslims and suspected the state government was unable to guarantee them fair justice procedures (Int. 31, 2019).

Underlying the above disputes, were competing claims over jurisdiction. In Nigeria, the federal government is empowered to establish a commission only where its remit concerns the actions of the federal government (or a branch of it, such as the army or police) and/or it occurs in Abuja Federal Capital Territory (Oyieke 2020). All other commissions should be instituted at state level. However, the extent to which cycles of violence in Jos fell under federal jurisdiction was interpreted variously by respondents.

By way of illustration, one respondent maintained that if perpetrators were caught but were 'foreign' to the state, the state government had to refer the case to the federal government, after which it was unclear whether they went to trial. This signalled a lack of transparency and undermined confidence in the accountability process (Int. 8, 2018). Several other respondents, including representatives of the state government, spoke of perpetrators being 'taken to Abuja', synonymous with federal government interference (Ints 23, 24, 26, 2018). A former senior official from the Ministry of Justice confirmed that cases of suspects who were caught with arms were taken over by the federal government (Int. 25, 2018). He declared that at the time, the state government had written to the federal Attorney General to ask for suspects to be handed back to Plateau State authorities for local prosecution. ${ }^{2}$ This was granted, but many suspects were not handed over. As a result, this respondent spoke with deep suspicion of the federal government, commenting:

Legal justice procedures in this country are flawed ... the federal government can actually frustrate whatever judicial process you are taking as a state ... To a large 
extent they [State Government] can't do anything because it's at the goodwill of whoever is in charge of security at the federal level. (Int. 26, 2018)

Another government respondent echoed these sentiments, describing 'frustrated' efforts on the part of state-level authorities to prosecute suspects (Int. 2, 2018). Together, these remarks highlight not only the challenges fragmented, multi-level governance can pose for accountability processes generally, but also that they can prove obstructive even for those who see themselves as pro-accountability actors and champions within the state architecture. In other words, even some within the state, who saw themselves as actively working to deliver accountability, shared some of the frustrations of civil society actors mobilising from outside the system.

While the absence of legal justice could to some extent be caused by a lack of clarity over jurisdiction and responsibilities on the part of state and federal governments, and the inability of both to resolve this, the consultations reveal deeply rooted suspicions among some about existing networks between senior officials and suspected perpetrators or sponsors of violence. Rumours about informal networks within federal and state governments, and elites working to protect certain groups, persist to this day, and are an indication of how multilevel, networked governance functions in Plateau State.

Overall, consultations highlighted that the state had failed to take COI recommendations forward and some perceived this as deliberate obstruction of justice and an impediment to peace. Respondents across communities indicated that the perceived lack of action in implementing recommendations of successive COIs has had detrimental effects on legitimacy and public trust. It has led to strong feelings about the state protecting individuals responsible for instigating violence, thus sustaining impunity.

CIVIL SOCIETY, COMMISSIONS AND ACCOUNTABILITY

Civil society in Plateau State is active and diverse. Many organisations and associations work as interest groups for specific ethnic and religious communities, whereas several peacebuilding groups exist that cut across ethnic and religious lines.

The most important way in which civil society actors formally engaged with the COI process was by submitting memoranda and sending representatives to give oral testimonies during hearings. In order to compile and present these contributions, CSOs conducted their own investigations into crises by visiting and speaking with affected communities. Secondly, CSOs worked to raise awareness of COI processes and help communities write their own submissions, thus enabling them to take part in the process. One respondent recalled that his organisation actively encouraged people to engage with COIs, saying that CSOs 'should help in calming nerves and urging the people, for instance, that the best way to ventilate their grievance is before the tribunal' (Int. 19, 2018).

Beyond investigations and hearings themselves, CSOs also engaged with resulting reports, such as by issuing press releases calling on the government 
to release reports and discuss recommendations (Right to Know 2010: 2).3 Certain organisations, like Right to Know, mobilised to 'unearth' reports that had been kept out of the public domain for years, and actively campaigned for the implementation of recommendations. Some interviewees reported that they raised concerns about the government's failure to implement recommendations (Int. 11, 2018).

This section analyses how, in the context of inter-group violence and interestbased civil society mobilisation, those in favour of 'hard' accountability competed with those in favour of more reconciliatory approaches. In effect, broad-based, collective action did not emerge in this context, which ultimately determined the extent to which civil society was able to pressure other actors in the accountability chain to implement recommendations.

\section{Civil society expectations of COIs and perceptions of accountability}

For several years, civil society actors maintained hope that COIs would be an effective measure to contribute to peace and justice, and so the establishment of COIs became a key demand of civil society actors.

The diverse motivations for this demand are a first indication of the varied interests of civil society actors. At the international level, civil society actors emphasised 'hard accountability'. In their official submission to the COI and Presidential Panel of Investigation set up to investigate the 2008 violence, Human Rights Watch contended: 'These investigative bodies should ensure that their findings are made public and call on government authorities to prosecute without delay those responsible for the killings and destruction of property, irrespective of which side of the conflict they are on' (HRW 2009: 1-2).

By contrast, interviews reveal how local and national civil society perceived tensions and trade-offs between peace and 'hard accountability'. In terms of the manner in which commissions operated, one respondent argued that some COIs had operated in a manner that was 'too legalistic': the language used in sessions was inaccessible, jargonistic, and in some cases lawyers accompanied those who gave their testimonies because they were afraid to use the wrong language (Int. 7, 2018). Reflecting an alternative view, two respondents felt that a weakness of commissions was that they had no power to summon critical witnesses, which would result in a lack of balanced evidence (Ints 2, 8, 2018). Similarly, another respondent felt that COIs could not operate sufficiently like a court of law and pass judgement and enforce punishment. Lastly, one respondent, remarking on the difference between early COIs and later committees, remarked that committees operated more like 'investigators', drawing an analogy to a police inquest, whereas COIs had created a space for listening that was better appreciated (Int. 20, 2018).

These diverging views reflect the fact that the expectations of civil society were themselves highly diverse. Some groups wanted COIs to produce 'soft' accountability by privileging truth-telling over investigative approaches; while others wanted COIs to operate in a more legalistic form and produce 'hard' 
accountability leading to convictions. Respondents diverged strongly in their perspectives on the trade-off between accountability through legal justice and reconciliation:

Most of these Commissions of Inquiries do not promote genuine reconciliation, they end up tagging people: either these are the victims or these are the perpetrators. So it doesn't in any sense promote reconciliation, the end result should have been a reconciliation and healing of wounds so we can have a genuine reconciliation and also have sustainable peace but they don't do that. (Int. 28, 2018)

Community groups organised around ethnic and religious lines had additional expectations and demands. A leader of one ethnic association remembered they had 'definitely requested that there was a need for even a Judicial Commission of Inquiry, not just a panel' following the 2001 crisis (Int. 7, 2018). Their expectation was that a COI would investigate the root causes of conflict, whereas a panel would be limited to investigating immediate triggers, events and perpetrators. Representatives from a Yoruba association stated they had appealed to the state government to establish a COI to ensure it was officially recorded that Yoruba communities were also affected by violence, not just the three main 'indigene groups' (Int. 16, 2018). They also hoped that this would lead to compensation for the loss of assets. Hausa-Fulani representatives expressed the hope that COIs would offer another opportunity to attain 'indigene' rights and status (Int. 8, 2018).

In this way, the hearings were seen by some as a new battleground, with groups trading accusations and thus potentially renewing tensions. A civil society representative who had been actively involved in the Niki Tobi COI recalls how members of contending groups had attended the hearings with their 'teams of lawyers ... Both the Christians and the Muslims were all prepared to go and do a lot of legal fireworks' (Int. 12, 2018). One interviewee from an inter-faith CSO noted that this affected the work of the COI as it distracted from the deep causes of the conflict, as well as from truth-telling and reconciliation (Int. $12,2018)$. While civil society groups that worked across ethnic divides emphasised the possibility that truth-telling could help build peace, another respondent questioned the role of COIs altogether: 'Hostilities will cease but the Commission of Inquiry itself becomes a stage for exchange of salvoes [gun fire]' (Int. 28, 2018).

Ultimately, COIs, rather than becoming a space for reconciliation, became another space for contestation between different groups; a clear indication of how COIs are embedded in local contexts and in this case, became part of conflict dynamics. The divisions in society, reflected in divergent expectations and demands of COIs, shaped civil society's engagement with commissions, their resulting reports and their demands on the government.

\section{Fragmentation and civil society action}

Compounding these divergent expectations, divisions in civil society inhibited civil society from mobilising collectively and exerting the necessary pressure 
on government actors to prompt forms of horizontal accountability. This did not mean there was no collaboration at all: some groups bargained with other groups on specific interests, as this section demonstrates, but concerted, collective action for accountability remained elusive, and this is considered key to successful accountability processes (Fox 2015, 2020).

From the outset, CSOs were often divided about the composition of COIs. Contending groups disagreed over whether and how different groups should be represented, affecting perceived neutrality (Ints 4, 19, 2018). Several CSOs reported they had actively 'screened' nominated COI members, especially the chairperson, and would publicly announce disagreement if they found that 'anyone has been compromised or is not qualified' (Int. 9, 2018). Respondents recalled disagreement over the appointment of Major General Abisoye as chairperson of the panel set up in 2008, because he had presided over the military tribunal that tried and executed prominent members of groups referred to as 'indigene' from Plateau State for their involvement in the 1976 coup (Akinwale 2010: 133). Fueling debates in the public domain was an important strategy to influence public perceptions of a COI, which could then influence how civil society and the public at large engaged with its work.

The ways in which different parts of government are perceived and accused of 'bias' is another example of how groups interpreted actors and networks in relation to their interests, and reflects the role of the state itself as an actor in the conflict. In the case of Ajibola Commission, suspicions of bias led HausaFulani groups to oppose its establishment. One respondent, reflecting deepseated fears at the time, shared that some members felt 'that the State Government was behind that crisis and it planned the crisis with the view to see that most of the Hausas were terrorised, killed or chase out of their house' (Int. 31, 2019). Others noted that the government's role in the violence informed calls for community members not to take part in the inquiry (Ints 3o, 33, 2019). Another respondent reported having personally issued a media statement calling on Hausa-Fulani in Jos to boycott the COI. He recalled how the State Governor announced on the first day of the 2008 crisis that 'the riot was started by Muslim youths in Ali Kazaure'. The respondent felt that in doing so, this Governor, as a political leader for all, had taken sides. The same respondent reasoned that:

The nature of the conflict also determined how a Commission of Inquiry is received, if it is a conflict between a community or a group or with the government or any of the government agencies, you see, it looks naturally that "okay, you (the state government) are the judge in your own ... case". (Int. 28, 2018)

He stated that he and his community therefore engaged with the Abisoye Panel, as they did not trust the state government and, by extension, the Ajibola COI, to be fair and just. He concluded: 'How they [COIs] come about and the political atmosphere, you know ... the environment at the time of their setup is what determines the shape they take and also the response they get' (Int. 28, 2018). 
Allegations made by civil society actors about networks between elites at federal and state level that would protect the interests of certain groups echo the rumours discussed above regarding impunity. Some respondents maintained that the state and federal governments are biased and on the side of particular groups. In broad terms, state government was accused of siding with the main 'indigene' groups and the federal government of siding with 'settler' groups, which would influence how each group engaged with COIs (Int. 16, 2018; Int. 31, 2019).

Once established, some respondents noted that diverse interests among civil society groups limited opportunities for coordination and effective collaboration once inquiries were underway:

No, I don't think we have liaised [with other groups]. We have been more or less focussed [on our group's point of view] because we have a non-interest. Other actors have their own interest. Sometimes is even very difficult ... even the indigenous groups themselves don't even sit at one common platform so it will be difficult to do. (Int. 7, 2017)

However, civil society collaboration was not absent altogether. Rather, bargaining and collaboration among ethnic associations takes place, but is very much interest-based and depends on the sensitivity of an issue. Peacebuilding and human rights organisations that were not ethnically aligned were more likely to collaborate to pressure government on COI recommendations. A representative from the Berom community explained it as such:

We try to just liaise with certain groups to be able to see our own interests, or to see our common stands on certain issues, but I don't think we have really relied on them [for collaboration], but we have to make our positions very clear and then push for them. (Int. 7, 2018)

Other examples include cooperation between a Hausa-Fulani association who collaborated with Igbo associations over the recommendation to reconstruct markets and commercial centres, and demands for compensation, despite their different positions on other matters. Representatives from Christian networks also said they had collaborated with Muslim religious leaders over the protection of places of worship. However, issues related to 'indigene' and 'settler' rights and citizenship were deeply divisive and 'frontiers nobody wants to cross', according to a journalist (Int. 23, 2018). The issue of prosecution was also heavily contested, with each group wanting to protect their own, especially when named suspects were important leaders. The representative of a women's organisation, which has worked across ethnic divisions, said:

Sometimes we have politicians themselves trying to get their tentacles into civil society to cause that dissipation of energy, or to make sure there is no unity of purpose. Civil society itself is fragmented by politicised interest, so who is civil society? Civil society itself is fractured. (Int. 14, 2018)

Apart from civil society being fragmented, delays in publishing reports also meant that momentum to act on COI recommendations waned. 
Organisations prioritised other, ongoing activities, sensing that peacebuilding activities and dialogues were more likely to contribute to peace than pushing the government on COI recommendations. CSOs working for the interests of those referred to as 'settler' communities carried on advocating for more political inclusion. This, too, has potential long-term implications for state legitimacy and cohesive authority in fragile contexts: one respondent specifically noted that through their work for justice, CSOs were taking on the work rightfully led by the state (Int. 32, 2019).

Regardless of the group to which one belonged, many interviewees reflected that the lack of responsiveness and hard accountability has had a longer-term impact on the perceived legitimacy of state institutions:

[The governments] just use them [COIs] so to placate people to be seen that government is interested in addressing crisis or resolving crisis and then after the commissions have done their work or whatever, writing beautiful reports then the reports are just there more or less gathering dust. (Int. 7, 2018)

Another respondent summarised: 'it became very monotonous; crisis will occur, we (the government) will set commission of inquiry to investigate, and at the end of the day reports are not implemented, so that has made the public lose confidence in their work', and suggested that the public would not be interested in any new COI (Int. 4, 2018). This exasperation was reflected in multiple respondents' accounts, with one remarking that COIs became, over time, 'just the routine that we do: when there is trouble, we set up the commission as a routine and then when the tempers cool down, government does not even care about the report anymore until another incident happens' (Int. 30, 2019). Another respondent echoed these sentiments, contending that the state's actions deepened the problem, 'for the simple fact that they failed to implement the first one, they allowed the problem to degenerate to such a level that it is increasingly becoming almost impossible to implement those recommendations again' (Int. 9, 2018).

\section{O N C L U S I O N}

This study has highlighted key factors associated with fragility in Nigeria's Middle Belt, and how they have shaped pathways to accountability in Plateau State. Existing research demonstrates that crises of credibility and issues of partiality undermine the ability of formal accountability mechanisms to deliver hard or soft accountability (Oyieke 2020). We propose that our understanding of these effects can be advanced through further consideration of the socio-political context in which COIs operate, specifically their position within the political architecture and in relation to civil society. Further, when established in fragile contexts, specific features of that context affect their functioning, including the contested and fragmented nature of authority, and divided civil society.

The findings show that COI processes themselves have helped bring about some limited degree of transparency and answerability, or 'soft' accountability 
$($ Fox $2007 a, 2007 b)$. Due to the investigative powers of COIs and their mandate to name perpetrators, they arguably contributed to answerability as the role of individuals and institutions was recorded in detail in reports. Violent events and their impact on communities were documented, and the voices of those affected were formally acknowledged. According to some, the process of providing testimonies helped to 'cool down' the volatile situation temporarily (Int. 30, 2019).

However, the findings also show that COIs were embedded in wider power dynamics and societal divisions, which were then reproduced in the work of commissions themselves. In this context of recurring violence, the mandate to 'name names' and recommend individuals for prosecution meant COIs became contested fora for competing interests within the state, between multiple levels of the state, and within and between deeply divided civil society actors. As a result, COI reports and the 'truths' they contained were not widely accepted.

With respect to 'hard' accountability, COIs have not been effective, neither in and of themselves as they cannot prosecute, nor by prompting government actors to do so. The fragmented nature of public authority, and the belief that this fragmentation mapped onto networks between political elites and leaders of different ethnic groups, were primary causes of this lack of enforcement. This eventually contributed to a lack of trust in both COI processes and the state.

However, explanations for the outcome of accountability processes that focus on state institutions alone neglect the important role civil society plays in shaping accountability pathways. Fragmentation within civil society-reflected in the diversity of demands and expectations on COIs, and in contestations between civil society groups in the course of inquiries - compounded the challenge COIs faced delivering 'hard' accountability. Whereas the literature recognises that civil society has an important role to play in maintaining pressure on governments to implement recommendations and enforce sanctions (Crocker 2000), momentum to act on COI reports waned. Before 2010, it seemed that many civil society actors believed that COIs could potentially contribute to justice and peace, but this hopefulness diminished due to the lack of government responsiveness. Many CSOs resumed their focus on peacebuilding and rights issues, disillusioned with the lack of political will to take COI recommendations further. At the same, civil society itself was so divided that it was unable to take concerted action either to pressure different state institutions and bolster horizontal accountability, or demand vertical accountability (Peruzzotti \& Smulowitz 2006).

The state was active in various peacebuilding initiatives and security responses to violence, but this study could not determine to what extent these efforts were a response to COI recommendations. Yet the interviews revealed diverging views within civil society on whether the absence of legal justice and accountability has caused further violence. In the context of Plateau State, it is uncertain whether prosecution and punishment would have led to peace. It is also unclear whether these would have effectively addressed the underlying causes of 
conflict. As is well-documented, the drivers of recurrent violence in Plateau State are rooted in the differentiated nature of citizenship across communities. Measures need to be in place to avoid the selective application of citizenship status (Sha 2005), and it is beyond the mandate of a single COI to resolve this.

\section{N O T E S}

1. 'Indigene' groups include Afizere, Anaguta and Berom communities; see Madueke (2018a) for a fuller discussion. Hausa and Fulani communities have separate histories and languages, but are often linked in Nigeria. The 'settler' communities stress they are 'Jasawa' as they have developed their own distinctive identity among the wider Hausa-Fulani, through which they emphasise that they, too, belong in Jos (Ostien 2009: 9).

2. Item number 2 on the Second Schedule of the 1999 Constitution of the Federal Republic of Nigeria (as Amended) gives the federal government legislative powers over 'arms, ammunition and explosives'. However, cases do not have to be referred to Abuja for trial. The states fought and won the case against transfer of accused persons to Abuja.

3. These strategies were also confirmed in Ints 1, 3, 11, 24 (2018).

\section{REFERE N C E S}

Ackerman, J. 2004. 'Co-governance for accountability: beyond "exit" and "voice", World Development 32, 3: $447-63$.

Ajibola Commission of Inquiry. 2009. Nigeria Judicial Commission of Inquiry Final Report. <http:// www.icla.up.ac.za/images/un/commissionsofinquiries/files/NIgeria \% 202009\% 20Jos \% 20commission \% 2ofinal\% 20report\%20_TORs.pdf $>$, accessed 05.02 .2018 .

Akinwale, A.A. 2010. 'Integrating the traditional and the modern conflict management strategies in Nigeria', African Journal of Conflict Resolution 10, 3: 123-46.

Albert, I.O. 1999. 'New directions in the management of community conflicts in Nigeria: insights from the activities of AAPW', in O. Otite \& I. O. Albert, eds. Community Conflicts in Nigeria. Ibadan: Spectrum Books.

Angerbrandt, H. 2015. 'Religion, ethnicity and citizenship: demands for territorial self-determination in southern Kaduna, Nigeria', Journal of Contemporary African Studies 33, 2: 232-50.

Angerbrandt, H. 2018. 'Deadly elections: post-election violence in Nigeria', Journal of Modern African Studies $5^{6,1}: 143-67$.

Bagayoko, N., E. Hutchful \& R. Luckham. 2016. 'Hybrid security governance in Africa: rethinking the foundations of security, justice and legitimate public authority', Conflict, Security $\mathcal{E}$ Development 16 , 1: $1-32$.

Bakiner, O. 2014. 'Truth commission impact: an assessment of how commissions influence politics and society', International Journal of Transitional Justice 8: 6-3o.

Balint, J., J. Evans \& N. McMillan. 2016. 'Justice claims in colonial contexts: Commissions of inquiry in historical perspective', Australian Feminist Law Journal 42, 1: $75^{-96 .}$

Belloni, R. 2008. 'Civil society in war-to-democracy transitions', in A.K. Jarstad \& T.D. Sisk, eds. From War to Democracy: Dilemmas of peacebuilding. Cambridge: Cambridge University Press, 182-210.

Crocker, D.A. 2000. 'Truth commissions, transitional justice and civil society', in R.I. Rotberg \& D. Thompson, eds. Truth vs. Justice. Princeton, NJ: Princeton University Press, 99-121.

Daushep, K. 2018. 'Senator Mantu to engage Plateau PDP guber aspirants on consensus arrangements', Today NG, 18.9.2018, <https://www.today.ng/news/politics/2019-senator mantu-engage-plateau-pdpguber-aspirants-consensus-arrangement-15391 1>, accessed 20.9.2019.

Fox, J. 2007a. Accountability Politics: power and voice in rural Mexico. New York, NY: Oxford University Press.

Fox, J. 2007 b. 'The uncertain relationship between transparency and accountability', Development in Practice $17,4: 66_{3}-71$.

Fox, J. 2015. 'Social accountability: what does the evidence really say?', World Development 72: 346-61.

Fox, J. 2016. Scaling Accountability through Vertically Integrated Civil Society Policy Monitoring and Advocacy. Making All Voices Count Working Paper. <https://www.ids.ac.uk/publications/scaling-accountabilitythrough-vertically-integrated-civil-society-policy-monitoring-and-advocacy/>, accessed 1 7.9.2019. 
Fox, J. 2020. 'Contested terrain: International development projects and countervailing power for the excluded', World Development 132, 104978: 1-18.

Goetz, A-M. \& R. Jenkins. 2001. 'Hybrid forms of accountability: Citizen engagement in institutions of public-sector oversight in India', Public Management Review 3, 3: $3^{6} 3^{-8} 3$.

Gofwen, R. 2011 . 'A historical overview of ethno-religious conflict in Plateau State: government interventions and strategies', in O.J. Para-Mallam, ed. Finding Durable Peace in Plateau. Kuru, Nigeria: National Insititute for Policy and Strategic Studies, $10-45$.

Greenawalt, K. 2000. 'Trials, commissions, and investigating committees: the elusive search for norms of due process', in R.I. Rotberg \& D. Thompson, eds. Truth v. Justice: the Morality of Truth Commission. Princeton, NJ: Princeton University Press, 189-210.

Hagmann, T. \& D. Péclard. 2010. 'Negotiating statehood: dynamics of power and domination in Africa', Development and Change 41, 4: 539-62.

Hayner, P.B. 2006. 'Truth commissions: a schematic overview', International Review of the Red Cross 88, 862: $295^{-310 .}$

Hayner, P.B. 2011 . Unspeakable Truths: Transitional Justice and the Challenge of Truth Commissions. London: Routledge.

Higazi, A. 2008. 'Social mobilization and collective violence: vigilantes and militias in the Lowlands of Plateau State, Central Nigeria', Africa 78, 1: 107-35.

Higazi, A. 2011. The Jos Crisis: A Recurrent Tragedy. Friedrich Ebert Stiftung Discussion Paper, No. 2. <https://library.fes.de/pdf-files/bueros/nigeria/o7812.pdf>, accessed 17.9.2019.

Human Rights Watch (HRW). 2009. Arbitrary Killings by Security Forces: Submission to the Investigative Bodies on the Novermber 28-29, 2008 Violence in Jos, Plateau State, Nigeria, <https://www.hrw.org/ news/2008/12/19/nigeria-arbitrary-killings-security-forces-jos $>$, accessed 17.9.2019.

Human Rights Watch (HRW). 2013. "Leave Everything To God": Accountability for Inter-Communal Violence in Plateau and Kaduna States, Nigeria. <https://www.hrw.org/report/2013/12/12/leave-everything-god/ accountability-inter-communal-violence-plateau-and-kaduna>, accessed 1 7.9.2019.

Jain, M. 2020. "Lawfare”, instruments of governmentality and accountability, or both? An overview of national commissions of inquiry in Africa', in T. Probert \& C. Heyns, eds. National Commissions of Inquiry in Africa: Vehicles to Pursue Accountability for Violations of the Right to Life? Pretoria: Pretoria University of Law Press, $45^{-69}$.

Joshi, A. 2017. 'Legal empowerment and social accountability: complementary strategies toward rightsbased development in health?', World Development 99: 160-72.

Kent, L. 2016. 'Sounds of silence: Everyday strategies of social repair in Timor-Leste', Australian Feminist Law Review 42, 1: 31-50.

Kim, H. \& K. Sikkink. 2010. 'Explaining the deterrence effect of human rights prosecutions for transitional countries', International Studies Quarterly 54: 939-963.

Krause, J. 2011. A Deadly Cycle: Ethno-Religious Conflict in Jos, Plateau State, Nigeria. Geneva: Geneva Declaration Secretariat.

Krause, J. 201 7. 'Non-violence and civilian agency in communal war: evidence from Jos, Nigeria', African Affairs 116, 463: 261-83.

Leonard, D.K. 2013. 'Social contracts, networks and security in tropical Africa conflict states: an overview', IDS Bulletin 44, 1: 1-14.

Maclean, M. 2001. 'How does an inquiry inquire? A brief note on the working methods of the Bristol Infirmary Inquiry', Joumal of Law and Society 28, 4: 590-601.

Madueke, K.L. 2018a. 'Routing ethnic violence in a divided city: walking in the footsteps of armed mobs in Jos, Nigeria', Journal of Modern African Studies 56, 3: 443-7o.

Madueke, K.L. $2018 b$. 'From neighbours to deadly enemies: excavating landscapes of territoriality and ethnic violence in Jos, Nigeria', Journal of Contemporary African Studies 36, 1: 87-102.

Méndez, J.E. 1997. 'Accountability for past abuses', Human Rights Quarterly 19, 2: $255^{-82 .}$

Menkhaus, K. 2008. 'The rise of a mediated state in Northern Kenya: the Wajir story and its implications for state-building', Afrika Focus 2 1, 2: 23-38.

Obateru, T. 201 2. 'Plateau Government condemns Abubakar's appointment as IGP', Vanguard, 26.1.2012, <https://www.vanguardngr.com/2012/o1/plateau-govt-condemns-abubakars-appointment-as-igp/>, accessed 20.9.2019.

Obateru, T. \& L. Binniyat. 2012. '2001 Jos crisis: Reactions trail AG IG's appointment', Vanguard, 27.1.2012, <https://www.vanguardngr.com/2012/01/2001-jos-crisis-reactions-trail-ag-igs-appointment/>, accessed 20.9.2019. 
O’Donnell, G. 1999. 'Horizontal accountability in new democracies', in A. Schedler, L. Diamond \& M.F. Plattner, eds. The Self-Restraining State: Power and Accountability in New Democracies. Boulder, CO: Lynne Rienner, 29-52.

O’Donnell, G. 2003. 'Horizontal accountability: the legal institutionalization of mistrust', In S. Mainwaring \& C. Welna, eds. Democratic Accountability in Latin America. Oxford: Oxford University Press.

Orjuela, C. 2005. 'Civil society in civil war: the case of Sri Lanka', Civil Wars 7, 2: 120-37.

Ostien, P. 2009. 'Jonah Jang and the Jasawa: ethno-religious conflict in Jos, Nigeria', Muslim-Christian Relations in Africa, August 2009 (online publication): 1-42. <https://ssrn.com/abstract=1456372>, accessed 8.10.2019.

Oyieke, A.Y. 2020. 'The (im)partiality of justice: the challenges of investigating the clashes between the Islamic Movement of Nigeria and the Nigerian army in Zaria, Nigera,' in T. Probert \& C. Heyns, eds. National Commissions of Inquiry in Africa: vehicles to pursue accountability for violations of the right to life? Pretoria: Pretoria University of Law Press, 279-311.

Peruzzotti, E. 2012. 'Broadening the notion of democratic accountability: participatory innovation in Latin America', Polity 44, 4: 625-42.

Peruzzotti, E. 2014. 'Accountability deficits of delegative democracy', in D. Brinks, M. Leiras \& S. Mainwaring, eds. Reflections on Uneven Democracies: the legacy of Guillermo O'Donnell. Baltimore, MD: Johns Hopkins University Press, 269-86.

Peruzzotti, E. \& C. Smulovitz. 200o. 'Societal accountability in Latin America', Journal of Democracy 11 , 4: $147-58$.

Peruzzotti, E. \& C. Smulovitz (eds) 20o6. Enforcing the Rule of Law: social accountability in the new Latin American democracies. Pittsburgh, PA: University of Pittsburgh Press.

Probert, T. 2017. Vehicles for Accountability or Cloaks of Impunity? How can National Commissions of Inquiry Achieve Accountability for Violations of the Right to Life? The Institute for Justice and Reconciliation, Policy Brief No. 25. <http://www.ijr.org.za/portfolio-items/policy-brief-no-25-vehicles-for-accountability-or-cloaks-of-impunity/>, accessed 16.9.2019.

Probert, T. 2020. 'The concept of accountability and its importance for the protection of the right to life', in T. Probert \& C. Heyns, eds. National Commissions of Inquiry in Africa: Vehicles to pursue accountability for violations of the right to life? Pretoria: Pretoria University of Law Press, $18-44$.

Probert, T. \& C. Heyns (eds) 2020. 'Introduction: the role of national commissions of inquiry in securing the supreme human right', in National Commissions of Inquiry in Africa: vehicles to pursue accountability for violations of the right to life? Pretoria: Pretoria University of Law Press, 1-17.

Raleigh, C., L. Linke, H. Hegre \& J. Karlsen. 2010. 'Introducing ACLED: An Armed Conflict Location and Event Dataset', Journal of Peace Research 47, 5: 651-6o.

Right to Know. 2010. 'Access to the Reports of Judicial Commissions of Inquiry on Jos Crisis.' <https:// r2knigeria.org/index.php/publication/r2k-publications/inquiry-on-jos-crisis/review-of-the-judicialcommissions-of-inquiry-on-the-conflicts-in-jos-plateau-state>, accessed 27.9.2021.

Ross, F.C. 2010. 'An acknowledged failure: women, voice, violence and the South African Truth and Reconciliation Commission', in R. Shaw, L. Waldorf \& P. Hazen, eds. Localizing Transitional Justice: interventions and priorities after mass violence. Stanford, CA: Stanford University Press, 69-91.

Rotberg, R.I. 2000. 'Truth commissions and the provision of truth, justice, and reconciliation', in R.I. Rotberg \& D. Thompson, eds. Truth vs. Justice: the Morality of Truth Commission. Princeton, NJ: Princeton University Press, 3-21.

Rotberg, R.I. \& D. Thompson (eds) 200o. Truth v. Justice: the Morality of Truth Commission. Princeton, NJ: Princeton University Press.

Sayne, A. 2012. Rethinking Nigeria's Indigine-Settler Conflicts. USIP Special Report No. 31 1, <https://www. usip.org/publications/2012/o7/rethinking-nigerias-indigene-settler-conflicts >, accessed 16.o9.2019.

Sha, D.P. 2005. The Politicization of Settler-Native Identities and Ethno-Religious Conflicts in Jos, Central Nigeria. Ibadan: Stirling-Horden Publishers.

Suberu, R.T. 1993. 'The challenge of ethnic conflict: the travails of federalism in Nigeria', Journal of Democracy 4, 4: 39-53.

Suberu, R.T. 20og. 'Religion and institutions: federalism and the management of conflicts over Sharia in Nigeria', Journal of International Development 2 1, 4: 547-6o.

Titeca, K. \& T. De Herdt. 2011. 'Real governance beyond the "failed state": negotiating education in the Democratic Republic of the Congo', African Affairs 110, 439: $213^{-31}$.

Yusuf, H.O. 2018. 'Colonialism and the dilemmas of transitional justice in Nigeria', International Journal of Transitional Justice 12: 257-76.

Zvobgo, K. 2020. 'Demanding truth: the global transitional justice network and the creation of Truth Commissions', International Studies Quarterly 64, 3: 609-25. 


\begin{tabular}{|c|c|c|}
\hline No. & Role & Date of Interview \\
\hline 1 & Youth Movement representative & 13.1 .2018 \\
\hline 2 & Former Secretary to the Government & 20.1 .2018 \\
\hline 3 & Politician and ethnic association representative & 15.2 .2018 \\
\hline 4 & Human rights organisation representative & 23.1 .2018 \\
\hline 5 & Youth Movement representative & 27.1 .2018 \\
\hline 6 & Attorney, Plateau State government & 30.1 .2018 \\
\hline 7 & Council of Elders representative & 12.2 .2018 \\
\hline 8 & Politician and ethnic association representative & $4 \cdot 4.2018$ \\
\hline 9 & Private legal practitioner & 6.4 .2018 \\
\hline 10 & Muslim women organisation representative & 10.4 .2018 \\
\hline 11 & Chairperson of a Christian association & 28.8 .2018 \\
\hline 12 & Interfaith organisation representative & $5 \cdot 5 \cdot 2018$ \\
\hline 13 & Youth Movement representative & 8.5 .2018 \\
\hline 14 & Christian Women organisation representative & 6.9 .2018 \\
\hline 15 & Youth Movement representative & $5 \cdot 9 \cdot 2018$ \\
\hline 16 & Yoruba community representative & 12.9 .2018 \\
\hline 17 & Youth Movement representative & 20.9 .2018 \\
\hline 18 & Ethnic development association representative & 22.9 .2018 \\
\hline 19 & Human rights organisation representative & 21.9 .2018 \\
\hline 20 & Representative from a Human rights organisation & $5 \cdot 9 \cdot 2018$ \\
\hline 21 & Youth Movement representative & 18.9 .2018 \\
\hline 22 & Representative from a Human rights organisation & $19 \cdot 9 \cdot 2018$ \\
\hline 23 & Journalist & 5.10 .2018 \\
\hline 24 & Retired senior official, Ministry of Justice & 23.9 .2018 \\
\hline 25 & Journalist and former chair of a journalist association & 24.9 .2018 \\
\hline 26 & Senior official, Plateau State Government & 26.9 .2018 \\
\hline 27 & Senior official, Plateau State Government & $20.9 \cdot 2018$ \\
\hline 28 & Politician and representative of an ethnic association & 6.5 .2018 \\
\hline 29 & Former state governor & $9 \cdot 9 \cdot 2018$ \\
\hline 30 & Interfaith organisation representative & 8.6 .2019 \\
\hline 31 & Private legal practitioner & 27.7 .2019 \\
\hline 32 & Muslim women organisation representative & 23.8 .2019 \\
\hline 33 & Muslim religious organisation representative & 19.11 .2019 \\
\hline 34 & Women's organisation representative & 30.11 .2019 \\
\hline
\end{tabular}

